\title{
The IL18 rs1946518 and PTPN22 rs2476601 polymorphisms are not associated with adult- and childhood-onset type 1 diabetes mellitus
}

\author{
L.P. Campos ${ }^{1}$; V. Graciolo ${ }^{1}$; M. Welter ${ }^{1}$; M.S. Lopes ${ }^{1}$; S. Nesi-França ${ }^{2}$; \\ G. Picheth ${ }^{1}$; and F.G.M. Rego ${ }^{1}$ \\ ${ }^{1}$ Programa de Pós-graduação em Ciências Farmacêuticas, Universidade \\ Federal do Paraná, Curitiba, PR, Brasil \\ ${ }^{2}$ Unidade de Endocrinologia Pediátrica, Departamento de Pediatria, \\ Universidade Federal do Paraná, Curitiba, PR, Brasil \\ Corresponding author: F.G.M. Rego \\ E-mail: rego@ufpr.br; fgmrego@gmail.com
}

Genet. Mol. Res. 19 (4): gmr18686

Received October 24, 2020

Accepted November 12, 2020

Published November 30, 2020

DOI http://dx.doi.org/10.4238/gmr18686

\begin{abstract}
Type 1 diabetes mellitus (T1DM) is an autoimmune disease characterized by the destruction of pancreatic $\beta$-cells. Interleukins such as interleukin 18 (IL-18) and protein tyrosine phosphatase, nonreceptor type 22 (PTPN22) have been found to be associated with immune related diseases. We investigated a possible association of polymorphisms in IL-18 gene rs1946518 and PTPN22 rs2476601 with T1DM diagnosed in children (aged $\leq 14$ years) and adults (aged $\geq 18$ years) via a case-control study. In Euro-Brazilian children $(n=320)$ and adults $(n=291)$, patients with T1DM and healthy individuals (control) were genotyped for rs1946518 and rs2476601 using fluorescent probes (Taqman system). All groups were in the Hardy-Weinberg equilibrium. No significant differences were observed in the genotypes and allele frequencies for both polymorphisms. For the IL-18 rs1946518 A-allele, the minor allele frequencies for children, adults, healthy individuals, and T1DM were $49 \%$ (95\% CI, 43.0-55.0), 47.5\% (40-52), 47.9\% (43-53), and 51\% (45-57), respectively. For the PTPN22 rs2476601 T-allele in adults, controls and T1DM had frequencies of 7.3\% (4-10) and 6.7\% (4-10). In conclusion, these polymorphisms were not associated with T1DM onset in children or adults in this population.
\end{abstract}


Key words: Adult-onset T1DM; Childhood-onset T1DM; Polymorphisms; IL18; PTPN22; Case-control study

\section{INTRODUCTION}

Type 1 diabetes mellitus (T1DM) is an autoimmune disease caused by the immunemediated destruction of pancreatic $\beta$-cells (Yoon and Jun, 2005). Approximately 550,000 children aged 0-14 years have T1DM, with approximately 90,000 new cases diagnosed each year, worldwide; in Brazil, about 51,500 children and adolescents in this age group present T1DM (IDF, 2019). The precise incidence of new-onset T1DM in those aged above 20 years remains unknown; however, a large proportion of new-onset T1DM has been seen in adults (Weng et al., 2018).

T1DM is a polygenic condition, with major genetic risk factors located within the class II HLA region; however, around 60 recognized non-HLA loci have been associated with this disease (Robertson and Rich, 2018). Nevertheless, the genetic basis correlations among children, adolescents, and adults with T1DM individuals remain unclear (Zhu et al., 2019).

Autoimmune T1DM is believed to be a T helper 1 (Th1) lymphocyte-mediated disease occurring due to interferon gamma (IFN- $\gamma$ ) production. Different pathways induce IFN- $\gamma$ expression in different cell types, including the interleukin 18 (IL18)-mediated signaling pathway (Esmailbeig and Ghaderi, 2017). Moreover, several factors may contribute to the destruction of insulin-producing $\beta$-cells, including the cytokines secreted by T helper 1 and 2 (Th1 and Th2), subsets of T helper (CD41) cells (Yoon and Jun, 2005). As IL18 plays a pivotal role in autoimmunity, it is considered as a strong candidate for influencing T1DM (Esmailbeig and Ghaderi, 2017).

With increasing onset age, the clinical course of the disease tends to become milder and $\beta$-cell destruction is slower than that in childhood-onset T1DM (Ilonen et al., 2019). Analysis of $\mathrm{T}$ cells from the peripheral blood of patients with newly diagnosed T1DM revealed different cytokine expression patterns when stimulated by islet autoantigens depending on their age at diagnosis (Arif et al., 2014).

The human IL18 gene is located on 11q23.1, and it contains six exons over $20.8 \mathrm{~kb}$. The IL18 sequenced analyses revealed 91 polymorphic loci within a region of $23 \mathrm{~kb}$, including the proximal promoter and $500 \mathrm{bp}$ downstream of the gene (Thompson and Humphries, 2007). Moreover, five polymorphisms (G-656T, C-607A, G-137C, Tp113G, and $\mathrm{Cp} 127 \mathrm{~T}$ ) located in the IL18 promoter altered the transcriptional activity (Giedraitis et al., 2001, Kretowski et al., 2002).

IL18 overproduction in T1DM may be attributable to polymorphisms in regions with regulatory functions, and it is known that the polymorphism -607 C/A (rs1946518) located in the ILI8 promoter region alters $I L 18$ promoter activity by changing its transcription activity (Giedraitis et al., 2001, Kretowski et al., 2002). This polymorphism disrupts the potential cAMP-responsive element-binding protein-binding site, and higher promoter activity is associated with the $-607 \mathrm{C}$ allele compared to the $607 \mathrm{~A}$ allele (Giedraitis et al., 2001).

PTPN22 (protein tyrosine phosphatase, nonreceptor type 22) is another gene that encodes a key regulator of the immune response and is associated with various autoimmune diseases, including T1DM (Carr et al., 2009). The PTPN22 gene is a protein-coding gene 
that belongs to the nonreceptor class 4 group of the protein tyrosine phosphatase family. This gene is located on chromosome $1 \mathrm{p} 13$ and encodes a protein known as lymphoid-specific intracellular phosphatase (LYP). This protein binds to the adapter protein called calcineurin B-like, which is primarily involved in the negative selection of thymocytes and regulation of peripheral T cell activation. Variants in the PTPN22 gene are associated with the dysregulation of T-cell maturation, thereby leading to the development of autoimmune diseases, including T1DM (Ramu et al., 2019).

It has been reported that a polymorphism (SNP) in the PTPN22 gene, C1858T (rs2476601), causes an R620W amino acid substitution that restricts the ability of Lyp to negatively regulate $\mathrm{T}$ cell receptor signaling and causes alterations in the $\mathrm{B}$ cell receptor signal transduction (Rodriguez et al., 2015).

The genetic information gathered to date is dominated by pediatric-onset T1DM in European-ancestral populations. Therefore, genetic evaluation of non-European populations at all stages of the etiologic process in T1DM should identify the novel genetic factors that can be used to predict the genetic risk of T1DM (Robertson and Rich, 2018). For instance, we found an association between the polymorphism rs2476601 in the PTPN22 gene with childhood-onset T1DM in the Brazilian population (Welter et al., 2018).

The present study aimed to assess the role of polymorphisms rs 1946518 ILI8 and rs2476601 PTPN22 in susceptibility to childhood and adult-onset T1DM in a EuroBrazilian population.

\section{MATERIAL AND METHODS}

\section{Study subjects}

The clinical cohort and control groups, matched by gender, comprised 320 children aged $\leq 14$ years and 291 adults aged $\geq 18$ years with Euro-Brazilian ancestry. Healthy children classified as controls $(n=169)$ were selected from public schools in Curitiba, Paraná, South Region of Brazil, and healthy adult subjects $(n=150)$ were randomly selected from the blood bank donors at the Clinical Hospital of the Federal University of Paraná (HC-UFPR), Parana, Brazil. The T1DM subjects developed diabetes in childhood ( $n$ $=151$, childhood-onset) or adulthood ( $n=141$, adult-onset), based on the criteria of the International Society for Pediatric and Adolescent Diabetes (ISPAD) (Mayer-Davis et al., 2018) and the American Diabetes Association (ADA 2020). Patients with T1DM were recruited from the Clinical Hospital of the Federal University of Paraná, Brazil. All the recruited subjects provided written informed consent. The study population showed predominantly European ancestry and self-reported having white skin, being classified as Euro-Brazilians (Krieger et al., 1965, Pena et al., 2011). The study was approved by the Ethics Committee of the Federal University of Paraná, Brazil (CAAE 01038112.0.0000.0102 and 24676613.6.0000.0102).

\section{Genotyping}

Blood samples were collected from all subjects in ethylenediaminetetraacetic acid anticoagulant treated tubes. Total genomic DNA was extracted from the whole peripheral blood of all subjects using the salting-out method, as previously described (Lahiri and Nurnberger, 1991). To extract DNA, the $\mathrm{A}_{260 / 280}$ ratio (accepted $>1.8$ ) and concentration 
(adjusted to $20 \mathrm{ng} / \mu \mathrm{L}$ ) were measured with a Nano Drop 2000 spectrophotometer (Eppendorf, Germany).

The genotyping of IL18 rs1946518 and PTPN22 rs2476601 was performed using fluorescent probes TaqMan ${ }^{\circledR}$ (Taqman code: C_2898460_10 and C_16021387_20) in the 7500 Fast $^{\mathrm{TM}}$ Real-Time PCR (Life Technologies/Applied Biosystems, Foster City, CA, EUA). Briefly, the reaction mixture (final volume $8 \mu \mathrm{L}$ ) comprised $3.0 \mu \mathrm{L}$ TaqMan Genotyping Master Mix, $1.9 \mu \mathrm{L}$ ultrapure water, $0.1 \mu \mathrm{L}$ of fluorescent probes, and $3.0 \mu \mathrm{L}$ DNA $(20 \mathrm{ng} / \mu \mathrm{L})$ in each well of a 96 -well plate. The reaction conditions were recommended by the manufacturer: $10 \mathrm{~min}$ at $95^{\circ} \mathrm{C}(1 \mathrm{cycle})$, followed by 50 cycles of $15 \mathrm{~s}$ at $95^{\circ} \mathrm{C}$ and $90 \mathrm{~s}$ at $60^{\circ} \mathrm{C}$. The genotyping quality was $>98 \%$ for all samples measured by the software (7500 Fast SDS system software).

\section{Clinical and laboratory data}

Laboratory routine assays were determined by using an automated system (Architect Ci8200; Abbott Diagnostics, Santa Clara, CA) or Labmax 400 (Labtest, Lagoa Santa, MG) with reagents, calibrators, and controls provided by the manufacturer. Concentrations of 1,5-anhydroglucitol were measured enzymatically (GlycoMark, Inc., New York, NY). Glycated hemoglobin (HbAlc) was measured via immunoturbidimetry using Cobas Integra 400 plus (Roche Diagnostics, Basel, Switzerland).

\section{Statistical analyses}

Normality was tested using the Kolmogorov-Smirnov test. Parameters with normal distributions were compared using the Student's t-test (2-tailed) for independent samples. The Mann-Whitney U test was used to compare parameters with non-normal distributions. Categorical variables were compared using the chi-square test. Verification of the HardyWeinberg equilibrium), genotypic and allelic frequencies, as well as $95 \%$ confidence interval $(95 \% \mathrm{CI})$ for the minor allele frequency (MAF) were performed using the program DeFinetti (http://ihg.gsf.de/cgi-bin/hw/hwa1.pl). Odds ratios were calculated using http://vassarstats.net/index.html.

The allele frequencies in other populations were considered similar when the frequency of the MAF was within the $95 \%$ CI limit. All calculations were performed using the MedCalc version 17.6 (MedCalc Statistical Software bvba, Ostend, Belgium). A P value $<0.05$ was considered as statistically significant for all tests.

\section{RESULTS}

The children and adult groups were matched by gender. Adults were additionally matched by age (Table 1$)$. The childhood-onset T1DM group (12 years) was older ( $\mathrm{P}<$ 0.001 ) than the control group (10 years). The childhood-onset T1DM group presented 2.8 times more diabetic ketoacidosis compared with adult-onset ( 70.2 vs. $24.7 \%$, respectively) during diagnosis. The T1DM groups revealed poor glycemic control, considering a good glycemic control criterion for HbA1c $(<7.0 \%)$ and fasting glucose $(<7.2 \mathrm{mmol} / \mathrm{L})($ Table 1) (ADA 2020). 
Albumin was found at significantly higher concentrations in the adult-onset T1DM group than in the control group; however, both results were within the reference range. The concentrations of creatinine were significantly higher in the T1DM group (children and adults) than those in their respective control groups (Table 1). In contrast, the creatinine concentration in both T1DM groups suggested no manifestation of renal damage, as the levels were close to the reference range (Ceriotti et al., 2008).

Table 1. Anthropometric and laboratory data in the child and adult groups.

\begin{tabular}{|c|c|c|c|c|c|c|}
\hline Parameters & $\begin{array}{l}\text { Control } \\
(n=169)\end{array}$ & $\begin{array}{l}\text { Children } \\
\text { Childhood- } \\
\text { onset T1DM } \\
(n=151)\end{array}$ & P value & $\begin{array}{l}\text { Controls }(n= \\
\text { 150) }\end{array}$ & \begin{tabular}{l}
\multicolumn{1}{c}{ Adult } \\
Adult-onset \\
T1DM \\
$(n=141)$
\end{tabular} & P value \\
\hline $\begin{array}{l}\text { Gender } \\
\text { male/female }\end{array}$ & $91 / 78$ & $73 / 78$ & $0.303^{* *}$ & $53 / 97$ & $48 / 93$ & $0.817 * *$ \\
\hline Age (years) & $\begin{array}{l}10 \\
(10-11)\end{array}$ & $\begin{array}{l}12 \\
(9-13)\end{array}$ & $<0.001$ & $\begin{array}{l}44.0 \\
(40-49)\end{array}$ & $\begin{array}{l}45.0 \\
(34-52)\end{array}$ & 0.602 \\
\hline $\operatorname{BMI}\left(\mathrm{kg} / \mathrm{m}^{2}\right)$ & $\begin{array}{l}18 \\
(17-20)\end{array}$ & $\begin{array}{l}18 \\
(17-21)\end{array}$ & 0.805 & $27.0 \pm 4.2$ & $25.8 \pm 4.3$ & $0.018^{*}$ \\
\hline Z-score & $0.53 \pm 1.06$ & $0.24 \pm 0.99$ & $0.015^{*}$ & - & - & - \\
\hline $\begin{array}{l}\text { Diabetes duration } \\
\text { (years) }\end{array}$ & - & $4.1 \pm 3.1$ & - & - & $15.2 \pm 10.7$ & $<0.001^{*}$ \\
\hline $\begin{array}{l}\text { DKA at diagnostic, } \\
\%\end{array}$ & - & 70.2 & - & - & 24.7 & $<0.001^{* *}$ \\
\hline $\begin{array}{l}\text { DM Family history } \\
(\%)\end{array}$ & - & 65.6 & - & - & 69.2 & $0.473^{* *}$ \\
\hline $\begin{array}{l}\text { Glycemia } \\
(\mathrm{mmol} / \mathrm{L})\end{array}$ & $5.1 \pm 0.6$ & $14.2 \pm 6.6$ & $<0.001^{*}$ & $\begin{array}{l}5.3 \\
(4.7-5.9)\end{array}$ & $\begin{array}{l}9.5 \\
(5.9-13.8)\end{array}$ & $<0.001$ \\
\hline HbAlc (\%) & $\begin{array}{l}5.2 \\
(5.1-5.4)\end{array}$ & $\begin{array}{l}9.7 \\
(8.7-11.1)\end{array}$ & $<0.001$ & $\begin{array}{l}5.4 \\
(5.2-5.6)\end{array}$ & $\begin{array}{l}8.8 \\
(7.6-9.7)\end{array}$ & $<0.001$ \\
\hline Albumin $(\mathrm{g} / \mathrm{L})$ & $\begin{array}{l}42 \\
(40-46)\end{array}$ & $\begin{array}{l}43 \\
(40-44)\end{array}$ & 0.780 & $\begin{array}{l}39 \\
(38-40)\end{array}$ & $\begin{array}{l}41 \\
(38-43)\end{array}$ & $<0.001$ \\
\hline Creatinine & $\begin{array}{l}48.6 \\
(35-57)\end{array}$ & $\begin{array}{l}61.9 \\
(53-71)\end{array}$ & $<0.001$ & $\begin{array}{l}49.5 \\
(42-59)\end{array}$ & $\begin{array}{l}72.5 \\
(71-88)\end{array}$ & $<0.001$ \\
\hline
\end{tabular}

Values are reported as means \pm standard deviation, median (interquartile range), or number $(n)$ of individuals. Control, healthy subjects; T1DM, type 1 diabetes subjects; M, male; F, female; BMI, body mass index; Z-score (calculated using http://reference.medscape.com/calculator/body-mass-index-percentile-boy); DKA, diabetic ketoacidosis; HbAlc, glycated hemoglobin A1c. Probability $(P)$, Mann-Whitney U-test, * Student's t-test (two-tailed), or **chi-square test. $P$-values in bold are significant $(P<$ $0.05)$.

The allele and genotype frequencies of IL18-607C (rs1946518) were similar in all groups studied; therefore, they were not associated with T1DM regardless of the age of disease onset (Table 2).

The frequencies of C1858T (rs1946518) genotypes and alleles were not significantly different between T1DM adult patients and the control group. Moreover, rs 1946518 was not associated with adult-onset T1DM. The genotype frequencies of the IL18 -607C (rs1946518) and PTPN22 C1858T (rs2476601) were in accordance with Hardy-Weinberg equilibrium in all groups (Tables 2 and 3). 
Table 2. Genotype and allele frequencies for the polymorphism rs 1946518 ILI8 in the study groups.

\begin{tabular}{|c|c|c|c|c|c|c|}
\hline Genotypes & $\begin{array}{l}\text { Control } \\
(n=169)\end{array}$ & $\begin{array}{l}\text { Childhood- } \\
\text { onset T1DM ( } n \\
=151)\end{array}$ & $P$ value & $\begin{array}{l}\text { Control } \\
(n=150)\end{array}$ & $\begin{array}{l}\text { Adult-onset } \\
\text { T1DM } \\
(n=141)\end{array}$ & $P$ value \\
\hline rs1946518 & & & & & & 0.251 \\
\hline $\mathrm{C} / \mathrm{C}$ & $50(29.6)$ & $39(25.8)$ & & $31(20.6)$ & $41(29.0)$ & \\
\hline $\mathrm{C} / \mathrm{A}$ & $76(45.0)$ & $76(50.3)$ & 0.616 & $85(56.6)$ & $71(50.4)$ & \\
\hline $\mathrm{A} / \mathrm{A}$ & $43(25.4)$ & $36(23.9)$ & & $34(22.8)$ & $29(20.6)$ & \\
\hline $\begin{array}{l}\text { A allele } \\
{[95 \% \mathrm{CI}]}\end{array}$ & $\begin{array}{l}47.9 \\
{[43.0-53.0]}\end{array}$ & $\begin{array}{l}49.0 \\
{[43.0-55.0]}\end{array}$ & 0.785 & $\begin{array}{l}51.0 \\
{[45.0-57.0]}\end{array}$ & $\begin{array}{l}45.7 \\
{[40.0-52.0]}\end{array}$ & 0.205 \\
\hline $\begin{array}{l}\text { Dominant model } \\
\mathrm{CC} \text { vs. } \mathrm{CA}+\mathrm{AA}\end{array}$ & $50 / 119$ & $39 / 112$ & 0.454 & $119 / 31$ & $41 / 100$ & 0.097 \\
\hline $\begin{array}{l}\text { Recessive model } \\
\text { AA vs. CC + CT }\end{array}$ & $43 / 126$ & $36 / 115$ & 0.740 & $24 / 116$ & $102 / 29$ & 0.916 \\
\hline
\end{tabular}

Values are reported as $n(\%)$. Probability (P), chi-squared test for genotype and allele frequencies $95 \% \mathrm{CI}=95 \%$ confidence interval. Dominant model (CC vs. CA + AA). Recessive model (AA vs. CA + CC). Hardy-Weinberg equilibrium $(P$-value) for rs 1946518 in healthy children controls $(0.198)$, for childhood-onset T1DM $(0.931)$, in adult healthy controls $(0.101)$, and adult-onset T1DM (0.863)

Table 3. Genotype and allele frequencies for the polymorphism rs 2476601 in PTPN22 in the study groups.

\begin{tabular}{|c|c|c|c|}
\hline Genotypes & $\begin{array}{l}\text { Control } \\
(n=150)\end{array}$ & $\begin{array}{l}\text { Adult-onset T1DM } \\
(n=141)\end{array}$ & P value \\
\hline rs2476601 & & & 0.211 \\
\hline $\mathrm{C} / \mathrm{C}$ & $128(85.0)$ & $124(87.9)$ & \\
\hline $\mathrm{C} / \mathrm{T}$ & $22(15.0)$ & $15(10.7)$ & \\
\hline $\mathrm{C} / \mathrm{C}$ & $0(0)$ & $2(1.4)$ & \\
\hline $\mathrm{T}$ allele & 7.3 & 6.7 & \\
\hline$[95 \% \mathrm{CI}]$ & {$[4.0-10.0]$} & {$[4.0-10.0]$} & 0.779 \\
\hline $\begin{array}{l}\text { Dominant model } \\
\text { CC vs. CT + TT }\end{array}$ & $130 / 22$ & $124 / 15$ & 0.324 \\
\hline $\begin{array}{l}\text { Recessive model } \\
\text { TT vs. CT + CC }\end{array}$ & $0 / 150$ & $2 / 139$ & $0.451^{*}$ \\
\hline
\end{tabular}

\section{DISCUSSION}

In this study, we investigated the role of polymorphisms rs1946518 IL18 and rs2476601 PTPN22 in susceptibility to childhood and adult-onset T1DM in the EuroBrazilian population. Brazilians are an admixture population mostly composed of Europeans, Africans and Native Americans (Gomes et al., 2018). This genetic background could explain the differences of alleles frequencies when compared to other populations, even with populations with more similar ancestors such as Caucasians, as in the case of the population studied in this work. Notably, allele frequencies for single nucleotide polymorphisms (SNPs) can vary by ethnic group, sometimes drastically (Ioannidis et al., 2004).

Interleukins (ILs) play a pivotal role in immune-related disorders. Proinflammatory cytokines, such as TNF- $\alpha$, IL-1 $\beta$, IFN- $\gamma$, IL-1 $\alpha$, IL-6, and IL-18, have been implicated in the pathogenesis of T1DM (Grunnet et al., 2009). Individual differences during inheritance of polymorphic cytokine genes (IL6,IL18,INF- $\gamma$ ) cause individual variations in the immune response. Therefore, cytokine gene polymorphisms may reflect or control the severity and 
duration of inflammation, and thus, the progression of various autoimmune diseases, including T1DM (Thompson and Humphries, 2007).

In a previous study, we showed that IL-6R rs2228145 was associated with T1DM development in adulthood (Campos et al., 2019).

Cytokine polymorphisms that modulate the degree of destruction and age of T1DM onset have already been described (Ide et al., 2002). Moreover, a significant difference was observed in the genotype distribution at position -137 IL18 (rs 187238) between patients depending on their age at T1DM onset (Mojtahedi et al., 2006, Altinova et al., 2010); however, the associations were contradictory. Altinova et al. (2010) found that polymorphism was associated with younger onset age, whereas Mojtahedi et al. (2006) found that it was associated only in older patients. Therefore, in the present study, we evaluated -607 IL-18 (rs1946518) in patients with adult- and childhood-onset T1DM.

Several studies have evaluated the influence of IL18 genetic variation on T1DM risk and have found dissonant results. This may be due to the influence of other genetic and environmental factors, which are likely to differ among the ethnic groups, or another gene locus nearby could be a region conferring major susceptibility to T1DM in humans, as the IL18 gene locus does not do the same (Nolan et al., 1998). Therefore, is not surprising that IL18 polymorphisms do not contribute to T1DM in certain populations. Boëchat-Fernandes et al. (2019) showed the rs1946518 A-allele from IL18 gene predisposes to early-onset T1DM in a Brazilian population with predominantly African ancestry subjects; nevertheless this effect was not observed in Brazilians with European or Native Amerindian ancestry. These findings reinforce the differences according to ethnic origin, especially for the admixed Brazilian population. Additionally, the IL18 rs1946518 was associated with other types of diabetes, such as increased prevalence of type 2 diabetes (Huang et al., 2010) and an increased risk to gestational diabetes (Tarnowski et al., 2017).

The genotypic and allelic frequencies did not differ between the study groups (Table 2). Similar results were found in other studies with Caucasian (Novota et al., 2005, Szeszko et al., 2006, Hadzija et al., 2013), Turkish (Altinova et al., 2010), Iranian (Mojtahedi et al., 2006), and Brazilian populations (Tavares et al., 2013). Some studies did not report any association between different 607 IL18 (rs 1946518) genotypes and the onset age in adult T1DM patients (Altinova et al., 2010), or T1DM in adults or Latent Autoimmune Diabetes of the Adult (LADA) (Novota et al., 2005), which was in accordance with our results; however, significant associations were found with T1DM in Asian populations (Dong et al., 2007, Lee et al., 2015).

The observed MAF (A) frequencies in the Brazilian population (Table 2) reveal that the healthy (child $43-53 \%$ and adult $45-57 \%$; 95\% CI) and T1DM (child $43-55 \%$ and adult $40-52 \%$; $95 \%$ CI) do not differ from the Northeast Brazilian population (control $46 \%$ and T1DM 43\%) (Tavares et al., 2013); nevertheless, they were higher than those observed in the African (control 35\%) (dbSNP), European (control 38.1\% and T1DM 39.2\%) (Szeszko et al., 2006), and Turkish (control 35.6\% and T1DM 35.7\%) populations (Altinova et al., 2010).

PTPN22 encodes the lymphoid specific phosphatase (Lyp) (Cohen et al., 1999), which prevents spontaneous T-cell activation (Hill et al., 2002), and hence PTPN22 deficiencies might induce proliferation of autoreactive lymphocytes in autoimmunemediated diabetes (Rodriguez et al., 2015); however, the $\beta$-cell destruction is slower in adult-onset T1DM than in childhood-onset T1DM (Ilonen et al., 2019). 
In a previous study, we already assessed rs 2476601 of the PTPN22 gene in a population of children with T1DM (Welter et al., 2018). The context of the present study offers the possibility of expanding the evidence and analyzing this polymorphism in the adult-onset T1DM.

No significant difference was observed in comparing genotypes $(\mathrm{P}=0.217)$ and allelic frequencies ( $\mathrm{P}=0.704)$; therefore, it is suggested that rs 2476601 of the PTPN22 gene is not associated with adult-onset T1DM in this population (Table 3); however, this polymorphism was associated with childhood-onset T1DM in a similar ethnic population by our research group. Analysis of the child cohort revealed that the frequency of the PTPN22 risk allele $(1858 \mathrm{~T})$ was significantly different in patients $(9.9 \%)$ than that in the controls (3.6\%; OR $=3.0,95 \% \mathrm{CI}=1.5-6, \mathrm{P}=0.01)$ (Welter et al., 2018).

The DR3/DR4-DQ302 risk genotype for T1DM is present more frequently in individuals with early disease onset (Caillat-Zucman et al., 1992). In contrast, reports of the effects of the age-on-diagnosis and non-HLA loci interaction are contradictory, with positive reports largely confined to studies involving small sample sizes (Todd et al., 2007; Espino-Paisan et al., 2011a; Espino-Paisan et al., 2011b).

Considering rs2476601 polymorphism, certain studies report that it is not related to the diagnosis age (Todd et al., 2007; Chagastelles et al., 2010; Howson et al., 2012; Tavares et al., 2015). Tavares et al. (2015) assessed the Brazilian population and found that the average age for the $\mathrm{C} / \mathrm{C}$ and $\mathrm{C} / \mathrm{T}+\mathrm{T} / \mathrm{T}$ genotypes in the dominant model for rs 2476601 polymorphism did not differ significantly. Although Howson et al. (2012) did not find a relationship between this polymorphism and the age at diagnosis of the disease, they observed gene-gene interaction, an association between the DR3/DR4-DQB1*0302 genotype and rs2476601 polymorphism $(\mathrm{P}<0.001)$. Differently, with a population with the same ancestry background as the one studied in this study, we have showed that TYK2 (tyrosine kinase 2) polymorphism rs2304256 was not associated with T1DM or the age of diabetes onset (Graciolo et al., 2019).

Type 1 diabetes is determined by a combination of environmental and genetic factors, whose may change with age (Robertson and Rich 2018). Relatively few studies have focused on late-onset T1DM, particularly in adults. Some studies found association between the rs1893217 in PTPN2 and rs2542151 near PTPN2 with T1D risk, especially an earlier T1D onset (Espino-Paisan et al., 2011a, Peng et al., 2015, Chen et al., 2019). The GWAS-derived GRS (genetic risk score) significantly predicted T1D risk and was associated with age in a Chinese population (Zhu et al., 2019). The correlations of the genetic basis among children, adolescents, and adults with T1DM in Brazilian individuals are still unclear. Knowledge of the genetic characteristics for each age group and ethnicity will be critical in order to facilitate early intervention in T1DM.

In this study, the frequency of the rs $2476601 \mathrm{~T}$ allele in the T1DM group was $6.7 \%$ (95\% CI, 4-10) (Table 3). This frequency was similar to the childhood-onset T1DM in South Brazil (9.9\%) (Welter et al., 2018), Northeast Brazil (8.0\%) (Tavares et al., 2015), and Italian (4.9\%) (Bottini et al., 2004) populations. The frequency of the $\mathrm{T}$ allele in the control group $(7.3 \%, 95 \% \mathrm{CI}, 4-10)$ (Table 3) was similar to that in the populations in the region of Rio Grande do Sul, Brazil (5.2\%) (Chagastelles et al., 2010), Italy (5.9\%) (Saccucci et al., 2008), Spain (6.7\%) (Santiago et al., 2007), and Germany (8.0\%) (Dultz et al., 2009). The frequency of both groups was higher than that reported for African (0.3\%) and Asian (1.7\%) populations. 
Our results suggest that the polymorphism IL18 -607C (rs 1946518) is not associated with both childhood and adult T1DM, and PTPN22 C1858T (rs2476601) is not associated with adult T1DM in the Euro-Brazilian population, South Brazil.

\section{ACKNOWLEDGMENTS}

This study was financed by $\mathrm{CNPq}$, Araucaria Foundation and by the Coordenação de Aperfeiçoamento de Pessoal de Nível Superior - Brasil (CAPES) - Finance Code 001.

\section{CONFLICTS OF INTEREST}

The authors declare no conflict of interest.

\section{REFERENCES}

ADA (2020). Standards of Medical Care in Diabetes-2020. Diabetes Care. 43(Suppl 1): S1-S2.

Altinova AE, Engin D, Akbay E, Akturk M, et al. (2010). Association of polymorphisms in the IL-18 and IL-12 genes with susceptibility to Type 1 diabetes in Turkish patients. J. Endocrinol. Invest. 33(7): 451-454.

Arif S, Leete P, Nguyen V, Marks K, et al. (2014). Blood and islet phenotypes indicate immunological heterogeneity in type 1 diabetes. Diabetes. 63(11): 3835-3845.

Boechat-Fernandes A, Rea RR, Romanzini NB, Gomes MB, et al. (2019). IL18 Gene Polymorphism Influences Age of Onset of DM1 in African Ancestry Brazilians. J. Pediatr. Genet. 8(1): 38-40.

Bottini N, Musumeci L, Alonso A, Rahmouni S, et al. (2004). A functional variant of lymphoid tyrosine phosphatase is associated with type I diabetes. Nat. Genet. 36(4): 337-338.

Caillat-Zucman S, Garchon HJ, Timsit J, Assan R, et al. (1992). Age-dependent HLA genetic heterogeneity of type 1 insulin-dependent diabetes mellitus. J. Clin. Invest. 90(6): 2242-2250.

Campos LP, Graciolo V, Sousa MM, Martins BR, et al. (2019). Polymorphisms rs1800795 of interleukin-6 and rs2228145 of interleukin-6 receptor genes in Euro-Brazilians with adult-onset type 1 diabetes mellitus. Genet. Mol. Res. 18(3): gmr18260.

Carr EJ, Niederer HA, Williams J, Harper L, et al. (2009). Confirmation of the genetic association of CTLA4 and PTPN22 with ANCA-associated vasculitis. BMC Med. Genet. 10: 121.

Ceriotti F, Boyd JC, Klein G, Henny J, et al. (2008). Reference intervals for serum creatinine concentrations: assessment of available data for global application. Clin. Chem. 54(3): 559-566.

Chagastelles PC, Romitti M, Trein MR, Bandinelli E, et al. (2010). Association between the 1858T allele of the protein tyrosine phosphatase nonreceptor type 22 and type 1 diabetes in a Brazilian population. Tissue Antigens. 76(2): 144-148.

Chen S, Fan H, Feng Y, Zhang Y, et al. (2019). The association between rs1893217, rs478582 in PTPN2 and T1D risk with different diagnosed age, and related clinical characteristics in Chinese Han population. Autoimmunity. 52(2): 95-101.

Cohen S, Dadi H, Shaoul E, Sharfe N, et al. (1999). Cloning and characterization of a lymphoid-specific, inducible human protein tyrosine phosphatase. Lyp. Blood. 93(6): 2013-2024.

Dong GP, Yu ZS, Liang L, Zou CC, et al. (2007). IL-18 gene promoter -137C/G and -607C/A polymorphisms in Chinese Han children with type 1 diabetes mellitus. Int. J. Immunogenet. 34(2): 75-79.

Dultz G, Matheis N, Dittmar M, Rohrig B, et al. (2009). The protein tyrosine phosphatase non-receptor type 22 C1858T polymorphism is a joint susceptibility locus for immunthyroiditis and autoimmune diabetes. Thyroid. 19(2): 143148.

Esmailbeig M and Ghaderi A (2017). Interleukin-18: a regulator of cancer and autoimmune diseases. Eur. Cytokine Netw. 28(4): 127-140.

Espino-Paisan L, de la Calle H, Fernandez-Arquero M, Figueredo MA, et al. (2011a). A polymorphism in PTPN2 gene is associated with an earlier onset of type 1 diabetes. Immunogenetics. 63(4): 255-258.

Espino-Paisan L, de la Calle H, Fernandez-Arquero M, Figueredo MA, et al. (2011b). Polymorphisms in chromosome region 12q13 and their influence on age at onset of type 1 diabetes. Diabetologia. 54(8): 2033-2037.

Giedraitis V, He B, Huang WX and Hillert J (2001). Cloning and mutation analysis of the human IL-18 promoter: a possible role of polymorphisms in expression regulation. J. Neuroimmunol. 112(1-2): 146-152. 
Gomes MB, Gabrielli AB, Santos DC, Pizarro MH, et al. (2018). Self-reported color-race and genomic ancestry in an admixed population: A contribution of a nationwide survey in patients with type 1 diabetes in Brazil. Diabetes Res. Clin. Pract. 140: 245-252.

Graciolo V, Welter M, Campos LP, Martins BR, et al. (2019). Brief Note Polymorphism V362F (rs2304256) of tyrosine kinase 2 is not associated with childhood- or adulthood-onset type 1 diabetes in southern Brazil. Genet. Mol. Res. 18(3): gmr18356.

Grunnet LG, Aikin R, Tonnesen MF, Paraskevas S, et al. (2009). Proinflammatory cytokines activate the intrinsic apoptotic pathway in beta-cells. Diabetes. 58(8): 1807-1815.

Hadzija MP, Korolija M, Jemin N, Pavkovic I, et al. (2013). Polymorphisms in the IL-18 and IL-12B genes and their association with the clinical outcome in Croatian patients with Type 1 diabetes. Gene. 512(2): 477-481.

Hill RJ, Zozulya S, Lu YL, Ward K, et al. (2002). The lymphoid protein tyrosine phosphatase Lyp interacts with the adaptor molecule Grb2 and functions as a negative regulator of T-cell activation. Exp. Hematol. 30(3): 237-244.

Howson JM, Cooper JD, Smyth DJ, Walker NM, et al. (2012). Evidence of gene-gene interaction and age-at-diagnosis effects in type 1 diabetes. Diabetes. 61(11): 3012-3017.

Huang Y, Xu M, Hong J, Gu W, et al. (2010). -607 C/A polymorphism in the promoter of IL-18 gene is associated with $2 \mathrm{~h}$ post-loading plasma glucose level in Chinese. Endocrine. 37(3): 507-512.

Ide A, Kawasaki E, Abiru N, Sun F, et al. (2002). Genetic association between interleukin-10 gene promoter region polymorphisms and type 1 diabetes age-at-onset. Hum. Immunol. 63(8): 690-695.

IDF (2019). IDF Diabetes Atlas. https://www.diabetesatlas.org, International Diabetes Federation.

Ilonen J, Lempainen J and Veijola R (2019). The heterogeneous pathogenesis of type 1 diabetes mellitus. Nat. Rev. Endocrinol. 15(11): 635-650.

Ioannidis JP, Ntzani EE and Trikalinos TA (2004). 'Racial' differences in genetic effects for complex diseases. Nat. Genet. 36(12): 1312-1318.

Kretowski A, Mironczuk K, Karpinska A, Bojaryn U, et al. (2002). Interleukin-18 promoter polymorphisms in type 1 diabetes. Diabetes. 51(11): 3347-3349.

Krieger H, Morton NE, Mi MP, Azevedo E, et al. (1965). Racial admixture in north-eastern Brazil. Ann Hum. Genet. 29(2): 113-125.

Lahiri DK and Nurnberger JI Jr (1991). A rapid non-enzymatic method for the preparation of HMW DNA from blood for RFLP studies. Nucleic Acids Res. 19(19): 5444.

Lee YH, Kim JH and Song GG (2015). Interleukin-18 promoter -607 C/A and -137 G/C polymorphisms and susceptibility to type 1 diabetes: A meta-analysis. Hum. Immunol. 76(8): 537-545.

Mayer-Davis EJ, Kahkoska AR, Jefferies C, Dabelea D, et al. (2018). ISPAD Clinical Practice Consensus Guidelines 2018: Definition, epidemiology, and classification of diabetes in children and adolescents. Pediatr. Diabetes. Suppl. 27: 7-19.

Mojtahedi Z, Naeimi S, Farjadian S, Omrani GR, et al. (2006). Association of IL-18 promoter polymorphisms with predisposition to Type 1 diabetes. Diabet Med. 23(3): 235-239.

Nolan KF, Greaves DR and Waldmann H (1998). The human interleukin 18 gene IL18 maps to 11q22.2-q22.3, closely linked to the DRD2 gene locus and distinct from mapped IDDM loci. Genomics. 51(1): 161-163.

Novota P, Kolostova K, Pinterova D, Novak J, et al. (2005). Interleukin IL-18 gene promoter polymorphisms in adult patients with type 1 diabetes mellitus and latent autoimmune diabetes in adults. Immunol. Lett. 96(2): 247-251.

Pena SD, Di Pietro G, Fuchshuber-Moraes M, Genro JP, et al. (2011). The genomic ancestry of individuals from different geographical regions of Brazil is more uniform than expected. PLoS One. 6(2): e17063.

Peng H, Li J, Chen X, Zhou X, et al. (2015). Genetic Variants of PTPN2 Gene in Chinese Children with Type 1 Diabetes Mellitus. Med. Sci. Monit. 21:2653-2658.

Ramu D, Perumal V and Paul SFD (2019). Association of common type 1 and type 2 diabetes gene variants with latent autoimmune diabetes in adults: A meta-analysis. J. Diabetes. 11(6): 484-496.

Robertson CC and Rich SS (2018). Genetics of type 1 diabetes. Curr. Opin. Genet. Dev. 50: 7-16.

Rodriguez A, Alfaro JM, Balthazar V and Pineda Trujillo N (2015). Association analysis of PTPN22, CTLA4 and IFIH1 genes with type 1 diabetes in Colombian families. J. Diabetes. 7(3): 402-410.

Saccucci P, Del Duca E, Rapini N, Verrotti A, et al. (2008). Association between PTPN22 C1858T and type 1 diabetes: a replication in continental Italy. Tissue Antigens. 71(3): 234-237.

Santiago JL, Martinez A, de la Calle H, Fernandez-Arquero M, et al. (2007). Susceptibility to type 1 diabetes conferred by the PTPN22 C1858T polymorphism in the Spanish population. BMC Med. Genet. 8: 54.

Szeszko JS, Howson JM, Cooper JD, Walker NM, et al. (2006). Analysis of polymorphisms of the interleukin-18 gene in type 1 diabetes and Hardy-Weinberg equilibrium testing. Diabetes. 55(2): 559-562.

Tarnowski M, Wieczorek A, Dziedziejko V, Safranow K, et al. (2017). IL16 and IL18 gene polymorphisms in women with gestational diabetes. Ginekol. Pol. 88(5): 249-254.

Tavares NA, Santos MM, Moura R, Araujo J, et al. (2013). Interleukin 18 (IL18) gene promoter polymorphisms are associated with type 1 diabetes mellitus in Brazilian patients. Cytokine. 62(2): 286-289. 
Tavares NA, Santos MM, Moura R, Araujo J, et al. (2015). Association of TNF-alpha, CTLA4, and PTPN22 polymorphisms with type 1 diabetes and other autoimmune diseases in Brazil. Genet. Mol. Res. 14(4): 1893618944.

Thompson SR and Humphries SE (2007). Interleukin-18 genetics and inflammatory disease susceptibility. Genes Immun. 8(2): 91-99.

Todd JA, Walker NM, Cooper JD, Smyth DJ, et al. (2007). Robust associations of four new chromosome regions from genome-wide analyses of type 1 diabetes. Nat. Genet. 39(7): 857-864.

Welter M, Volanski W, Alberton D, Franca SN, et al. (2018). Polymorphism rs2476601 in the PTPN22 gene is associated with type 1 diabetes in children from the South Region of Brazil. Gene. 650: 15-18.

Weng J, Zhou Z, Guo L, Zhu D, et al. (2018). Incidence of type 1 diabetes in China, 2010-13: population based study. $B M J .360$ : j5295.

Yoon JW and Jun HS (2005). Autoimmune destruction of pancreatic beta cells. Am. J. Ther. 12(6): 580-591.

Zhu M, Xu K, Chen Y, Gu Y, et al. (2019). Identification of Novel T1D Risk Loci and Their Association With Age and Islet Function at Diagnosis in Autoantibody-Positive T1D Individuals: Based on a Two-Stage Genome-Wide Association Study. Diabetes Care. 42(8): 1414-1421. 